\title{
Curcuma Longa (Medicinal Plant) Research: A Scientometric Assessment of Global Publications Output with Reference to Web of Science
}

\author{
Dr.K. Sivasekarana, Dr. Prabakar Stanleay ${ }^{b}$, Dr.P. Ashok Kumar ${ }^{c}$, Dr. Sivankalaid, \\ Dr.K. Sivasamy ${ }^{\mathrm{e}}$
}

aLibrarian, Ayya Nadar Janaki Ammal College, Sivakasi, India. E-mail: sivasekarank@ gmail.com ${ }^{b}$ Librarian, B.I.H.E.R. - Deemed to be University, Chennai, India. E-mail: stanleay@ gmail.com ${ }^{c}$ Librarian, Thiruvalluvar University Constituent Arts \& Science College, Kallakurichi, India. E-mail: ashokan47@gmail.com dLibrarian, PSN College of Engineering and Technology, Tirunelveli, India. E-mail: skysivan@ gmail.com ${ }^{\mathrm{e}}$ College Librarian, Thiru A. Govindasamy Govt. Arts College, Tindivanam, India. E-mail: k.shivaswamy@ gmail.com

Article History: Received: 11 January 2021; Accepted: 27 February 2021; Published online: 5 April 2021

\begin{abstract}
The present study explores the characteristics of publication records for a total duration of twenty years, from 2000 to 2019, in the field of Curcuma longa research. This study has been carried out based on the multidisciplinary bibliographic database available with the Web of Science in Science Citation Index-Expanded (SCIE) and Social Sciences Citation Index (SSCI) and its implications, using the means of scientometrics research techniques. In order to make this analysis a holistic and comprehensive survey of the research trends in the chosen field, the following variables are taken into account: growth rate; global citation scores; distribution of publications by journals, conferences and institutions; favored media of communication; Hirsch index and citation profile of top institutions, countries and authors; contribution of funding agencies; high number of cited papers and characteristics of their bibliographic details. The total number of publication records has been found out to be 6087 during the study period. These 6087 publications have received $171 \mathrm{~h}$-index, 1, 84,715 global citations score and 30.34 average citations. On the whole, 6087 records were published during the study period (2000-2019) in 18 types of documents from 107 countries with 2005 journals, contributed by as many as 20855 authors affiliated to 4879 institutions. These publications were brought out in 18 languages, and they received 1 , 56,986 cited references. Majority of the records were in the form of journal articles, reviews, papers in conference proceedings and meeting abstracts, accounting for 97 percent of the total publications. Naturally enough, English happens to be the leading language of 98.8 percent to have accounted for the most number of publications. The four largest contributing countries in the total literature on Curcuma longa during the entire study period are India (24.68 percent), USA (17.7 percent), China (12.2 percent) and Iran (6.09 percent) respectively. The largest institutional contributor of publication records happens to be the Mashhad University of Medical Sciences, Mashhad, Iran with 1.8 percent of the papers to its credit. The most prolific authors to have published more number of research documents during the study period were Sahebkar A (73 papers), Aggarwal BB (67 papers), Nayak S (35 papers) and Kumar A (33 papers). The journal of "Food chemistry" Elsevier ltd tops the list of journals with maximum number of publication records in the field for the given study period with 70 publications, followed by "Journal of Agricultural and Food Chemistry" American Chemical Society (69 papers), "Phytotherapy Research" John Wiley and sons Ltd (63 papers) and "PLOS One" Public Library of Science (59 papers). While the Third World Congress on Medicinal and Aromatic Plants - WOCMAP III held in February 2003 at Thailand resulted in the publication of 6 papers, the following three major funding agencies contributed immensely to the research activities in the field: 'National Natural Science Foundation of China' with 318papers, United States Department of Health \& Human Services, USA with 304 papers and Council of Scientific Industrial Research, India with 99 papers.
\end{abstract}

Keywords: Medicinal Plants, Curcuma Longa, Funding Agencies, Scientometric Study, Global Publications.

\section{Introduction}

Turmeric (Curcuma longa Linn) is a medicinal herb belonging to the family of Zingiberaceae, which is widely cultivated in the tropical and subtropical regions, having its origination from India, Indonesia and Southeast Asia (Paramasivam et al. 2009). It is used as spices and also used in traditional medicine for its widespread medicinal properties like anti-microbial, anti-oxidant, anti-inflammatory, anti-cancer, anti-aging and anti- malarial characteristics. These medicinal properties are ascribed to its compound Curcuminoids which consists of curcumin (CUR), Dimethoxy curcumin (DMC) and bisdemethoxy curcumin (BDMC). Among these curcuminoids, curcumin (diferuloylmethane) is the most predominant bioactive compounds with the presents of 
60 percent to 70 percent of crude turmeric extract. Turmeric also has proteins, sugars, resins and volatile oils (Kawasaki et al.2018).

CUR looks like a crystalline compound in a bright orange-yellow color. Curcuminoids are frequently used as coloring agents along with food additives. World Health Organization (WHO) has recommended the adequate daily intake of curcuminoids as a food additive in the range of $0-3 \mathrm{mg} / \mathrm{kg}$. Curcuminoids and turmeric products have been considered as safe by the Food and Drug Administration (FDA) in USA. The average intake of turmeric in the Indian diet is approximately 2 to $2.5 \mathrm{gm}$ for a $60 \mathrm{~kg}$ individual which corresponds to a daily intake of approximately 60 to $100 \mathrm{mg}$ of CUR (Mahmood et al.2015).

Curcuminoids are phenolic compounds commonly used as a spice, pigment and additive also utilized as a therapeutic agent used in several foods. Various clinical trials also suggest a prospective therapeutic role for curcuminoids in many chronic diseases such as cancer, lung cancer, breast cancer and inflammatory bowel diseases (Amalraj et al.2016). Curcuminoids also have ability to treat immune related, cancer and metabolic diseases with no side effects. (Siviero et al. 2015).

In Turmeric root extract of oleoresin, the main active components are the volatile oil and curcuminoids. These essential oils are made up of sesquiterpenes. The aroma of turmeric is due to the particles derived from a and $\mathrm{b}$ - turmerones and aromatic turmerone ( $\mathrm{Ar}$ - turmerone) (Ravindran et al.2007). Curcuminoids are less soluble in water at acidic and neutral $\mathrm{pH}$, but soluble in methanol, ethanol, dimethyl sulfoxide and acetone. The curcuminoids yield a yellow-orange coloration to turmeric due to the extensive electronic delocalization inside the molecules that exhibit strong absorption between 420 to $430 \mathrm{~nm}$ in an organic solvent. The curcuminoids are a mixture of curcumin, chemically a diferuloylmethane [1,7 -bis ( 4 - hydroxyl - 3 - methoxy - phenyl $)$ - hepta 1,6 - diene - 3,5 - dione] mixed with its two derivatives, demethoxy curcumin [4-hydroxycinnamoyl-(4hydroxy-3-methoxycinnamoyl) methane] and bis - demethoxy curcumin [bis - (4-hydroxy cinnamoyl) methane], defining the chemical formulae as $\mathrm{C} 21 \mathrm{H} 20 \mathrm{O}$, $\mathrm{C} 20 \mathrm{H} 18 \mathrm{O} 5$ and $\mathrm{C} 19 \mathrm{H} 16 \mathrm{O} 4$ respectively (Siviero et al. 2015).

Kim et al. (2009) reported CUR, curcumin C3 complex and tetra hydro curcuminoids (THC) have antidiabetic properties. Changtam et al. (2010a) stated that the curcuminoid components such as CUR, DMC and BDMC have been structurally modified to 55 analogs and anti - mycobaterial activity against Mycobacterium tuberculosis.

Mulik et al.2010 reported that using homogenization method, Transferrin -mediated curcumin solid lipid nanoparticles (Tf- CUR-SLNPs) were formulated for increasing the photo stability and in order to improve their anticancer activity against MCF-7 breast cancer cells. They stated that CUR has the high efficiency against MCF-7 breast cancer cells using targeting effect of Tf - Cur-SLNPs and confirmed the ability of proposed drug delivery in the treatment of breast cancer.

CUR can be a valuable drug for treating clinical and pathological abnormalities in PCOS condition (Reddy et al. 2016)

Chen et al. (2010) they reported that anti-influenza activity of CUR the treatment with $30 \mathrm{mMCUR}$ reduced the yield of virus by over 90 percent in cell culture. Cooney et al. (2016) investigated that reducing capacity of CUR against colon inflammation in the Mdr1 $\mathrm{a}^{----}$mouse model of human inflammatory bowel disease using a combined transcriptomics and proteomics approach.

Curcumin has been achieved to reduce Influenza A virus lung tissue injury by reducing the inflammatory cytokine production. Curcumin is a natural ligand of PPAR $-\gamma$, which represses and reduces the inflammatory cytokine production. So, it will possibly play a role in protecting lung injury associated with COVID (Ciavarella et al. 2020).

Richart et al. (2018) reported Curcumin has been proved to be efficient in treating HIV and other viruses including hepatitis B, hepatitis C, zika, chikungunya, dengue etc also have inhibitory effect due to curcumin (Prasad and Tyagi et al. 2015).

Consequently, Turmeric plant is a precious source for human welfare.

\section{Scientometrics}


Scientometrics is generally referred as a branch of information science that makes a qualitative as well as quantitative measurement of publication records in a given field of academic research. The tools of bibliometrics are often utilized for conducting Scientometric analysis. Derek J. de Solla Price and Eugene Garfield are considered to be the pioneers in the field of Scientometric research. The term 'Scientometrics' was however coined by Nalimov and Mulchenkoin the year 1969, who defined it (Scientometrics)as the application of quantitative methods of science for the purpose of analyzing the information process in scientific research. Scientometrics entered its modern phase and indeed had a new beginning with the advent of information and communication technology (ICT). The web-based digital / electronic databases offer a wide range of data relating to the research publications, citations, H-Index and so on, making it possible for the information scientists to study the research trends in any discipline.

\section{Objectives of the Study}

The primary objective of this research work is to study the performance and status of universal Curcuma longa publications during the last 20 years (2000-2019), supported by publications indexed in Web of Science database from Clarivate Analytics. In addition, this study focuses on the other related objectives such as distribution of Curcuma longa research output in terms of publications, citations, authors and h-index, most productive countries on the basis of citations, number of authors and h-index, most prolific authors with h-index, global institutions and citation score, major journals in terms of impact factor, publications in conferences, contribution of funding agencies and highly cited papers.

\section{Materials and Methods}

The required data were collected from Science Citation Index-Expanded (SCIE) and Social Sciences Citation Index (SSCI) using the "ISI Web of Knowledge" an international database of the Clarivate Analytics (version 4.10 -Web of Science), in September 2020. For the purposes of analysis, the aforesaid data on global publications in last twenty years (2000-2019) was collected in the form of electronic download. The Basic search was conducted using the keywords "Turmeric" or "Curcuma longa" or "curcumin" using the core collection of this database, and custom year range of time span 2000 to 2019 was chosen for arriving at the data results. Every 500 data was downloaded as a single component with full records, cited references and the plain text. Thus, a total number of 6087 publication records were obtained for the entire study period using this method. The downloaded data was then tabulated and analysed using the Histcite software and MS Excel for getting the relevant information required for analysis and interpretation.

Additionally, abstracts were included within the search range while using the specific keywords, so as to integrate publications relating to this study from the most related records for the special issue on the turmeric. As a pioneering study on this field of research encompassing such a vast time range, the search terms 'turmeric', 'Curcuma longa' and 'curcumin' were used, in order to arrive at a broader picture of the research in this area as much as possible. A more restricted use of the search terms in an earlier version of this study had affected the identification of literature, more particularly in the fields relating to the vital sciences.

Histcite software has been used for analyzing the result after the data was downloaded from the web of Science database. This software provided the result by analyzing few areas and by preparing tables with local citation scores and global citation scores. Total records have been shown through this software, and the analysis was carried out following the result outputs like Records, Authors, Journals, Cited References, Words, Yearly output, Document type, Language, Institution, and Institution with subdivision and Country.

The next step of this analysis was carried out using the "create citation report" tool of the Web of Knowledge database. The final results have been arrived at using the Total publications, sum of the times cited, Citing Articles, Without self citations, Average citations per item and h-index.

\section{Literature Review}

K.K Mueen Ahmed, B. M. Gupta and Ritu Gupta (2018) have examined the twenty years (from 1997 to 2016) of global research publications on curcuma longa in the database of Scopus with a total of 5351 publication records with citation impact, growth rate, collaborative share of papers, subject areas, output and citation of authors and organizations. The publication share of first 15 countries was 92.66 percent, while 340 publications received highest citations between 100 and 3869 during this period. 
Laksham, S et al. (2020) have examined the global level view of Coronavirus publication outputs by retrieving 7381 records for the period extending from 1989 up to March 2020. They have analyzed the annual publication growth, publication share in global, research communication channels pattern and journals' productiveness. Thus this article has concluded by stating that publication output of joint author's was higher when compared to the single author publications, and open access journals published higher than paid journals.

Gupta BM, Mueen Ahmed KK and Ritu Gupta (2018) have analyzed the publication records of Glycyrrhiza glabra in global using bibliographical database of Scopus for the total period of twenty years. They came up with the following results; average annual growth rate is 10.87 percent and 19.09 citations per year, China and India are the good number of productive countries 19.81 percent and 13.71 percent. 1153 journals published 3352 papers, twenty organizations in global level published 15.08 percent of the papers, 9.16 percent of the authors, and they received citation scores 14.57 percent and 16.62 percent in the study period. This study reveals that, Asian countries excelled in the total number of publication records more than the other countries in Glycyrrhiza glabra research, whereas the quality of research was found to be higher with American and western countries.

Konur, O (2011) has studied the scientometric evaluation of the research on the algae and bio-energy for the period of three decades extending from 1980 to 2009 using Web of ISI Web of Knowledge database. He has investigated the most prolific authors, countries, research institutions, journals, subject areas language of publications and most cited papers. The result of this study showed that the algae and bio-energy had developed exponentially in the past three decades.

B. M. Gupta, K. K. Mueen Ahmed (2018) have conducted a scientometric view on 4900 global publication outputs in the field of Azadirachta indica research during 1997 to 2016 . He measured to find out that the average annual growth rate stood at 7.61 percent and the citation score grew at the pace of 13.91 percent per paper. The largest share of publication records was found to have emerged from India with 53.49 percent and Agricultural and biological sciences contributed 48.41 percent. 20.65 percent and 8.92 percent of total share by first twenty five global organizations and authors and 43.63 percent of journal publications were shared among by the first 20 most prolific journals during the study period of 1997 to 2016.

Milad Haghania, Michiel C.J. Bliemer et al. (2020) analyse the bibliometric aspects of this studies on a macro level, as well as those addressing Coronaviruses in general. Moreover, through a scoping analysis of the literature on COVID-19, they have identified the main safety-related dimensions that these studies have thus far addressed.

Nirmal Singh (2017) explained the outlines of the growth of scientific literature on Azadirachta indica in the journals applying bibliometric analysis. The distribution of articles in journals was found nearly acceptable to the Bradford's law of scattering making it obvious that there are a few core journals contributing significantly on Azadirachta indica.

Anwar MA depicts that growth of the literature analyzed in this study indicates that research on Phoenix dactylifera L grew very fast from 1971 onward, reached its peak by 1989, and stabilized after that period. It clearly focused on the direction for plant diseases, plant breeding and the quality of augmenting the food and feed. There is a clear focus in research on improving plant breeding, supervision plant diseases, and augmenting the food and feed quality. The literature from medical feature plays more importance on the animal areas rather than the human areas.

Table 1. Publications, Citations, Author and h-index wise Distribution of Curcuma Longa Research Output

\begin{tabular}{llllllll}
\hline S. No & Years & TR & TCS & CPR & NA & NAPR & h-index \\
\hline 1 & 2000 & 58 & 3350 & 57.76 & 230 & 3.97 & 32 \\
2 & 2001 & 55 & 7941 & 144.38 & 251 & 4.56 & 38 \\
3 & 2002 & 68 & 6526 & 95.97 & 291 & 4.28 & 40 \\
4 & 2003 & 83 & 6343 & 76.42 & 371 & 4.47 & 39 \\
5 & 2004 & 92 & 6960 & 75.65 & 347 & 3.77 & 46 \\
6 & 2005 & 130 & 10998 & 84.60 & 573 & 4.41 & 52 \\
7 & 2006 & 157 & 10846 & 69.08 & 722 & 4.60 & 60 \\
8 & 2007 & 198 & 15223 & 76.88 & 897 & 4.53 & 63 \\
9 & 2008 & 218 & 15710 & 72.06 & 1011 & 4.64 & 57 \\
10 & 2009 & 276 & 13581 & 49.21 & 1269 & 4.60 & 62 \\
11 & 2010 & 296 & 11736 & 39.65 & 1413 & 4.77 & 60 \\
12 & 2011 & 311 & 10618 & 34.14 & 1414 & 4.55 & 53 \\
13 & 2012 & 354 & 10599 & 29.94 & 1759 & 4.97 & 54 \\
14 & 2013 & 435 & 11895 & 27.34 & 2190 & 5.03 & 55 \\
15 & 2014 & 398 & 11046 & 27.75 & 2026 & 5.09 & 50 \\
16 & 2015 & 491 & 10232 & 20.84 & 2554 & 5.20 & 44 \\
17 & 2016 & 512 & 6896 & 13.47 & 2584 & 5.05 & 37 \\
18 & 2017 & 573 & 7128 & 12.44 & 3117 & 5.44 & 36
\end{tabular}




\begin{tabular}{|c|c|c|c|c|c|c|c|}
\hline 19 & 2018 & 680 & 4676 & 6.88 & 3322 & 4.89 & 29 \\
\hline 20 & 2019 & 702 & 2351 & 3.35 & 3945 & 5.62 & 18 \\
\hline \multicolumn{2}{|c|}{ 2000-2009 } & 1335 & 97478 & & 5962 & & \\
\hline \multicolumn{2}{|c|}{ 2010-2019 } & 4752 & 87177 & & 24324 & & \\
\hline \multicolumn{2}{|c|}{ Total } & 6087 & 184708 & & & & \\
\hline
\end{tabular}

TR-Total Records TCS-Total Citation Scores CPP-Citation Per Records NAPR-Number of Authors per Records

The cumulated literature output in the field of Curcuma longa on the global scenario is 6087 for a 20 year period starting from 2000 up to 2019. The yearly output in Curcuma longa research increased from 55 in the year 2001 to 702 publications in 2019 on the global level. The second half of the study period 2010-2019 saw an increased number of publications and authors following the previous trend, but the number of citations became lower compared to the first decade of the twenty-first Century (2000-2009). The number of publications increased 3.6 times, and the number of authors increased 4 times between the beginning and ending years of the total study period. The years 2005 to 2014 witnessed a total gain of more than $50 \mathrm{~h}$-index, while it was lower than 50 in the rest of the study period years. This data reveals that the total number of researchers and their publications have attained a drastic growth in the field of Curcuma Longa research. Yet, the rather decreased number of citations and decline of H-Index below 50 may be indicating an alarming trend in the particular area of research. It is generally expected that more number of authors and research publications would lead to more citations and an increase in H-Index. It appears strange and alarming that citations and H-Index in this field of research.

Of the total global publication output in the field of Curcuma Longa research for the total study period, 4846 (79.6 percent) have appeared in the form of articles, while 659 (10.8 percent) were Reviews, 204 (3.4 percent) were conference papers, 199 publications were abstracts (3.3 percent), 69 were articles in proceedings (1.1 percent), 34 were editorials ( 0.6 percent), 23 were Letters ( 0.4 percent), 12 were corrections ( 0.2 percent), 9 were news items, 8 were article retracted publications, 7 were early access articles, 5 were review book chapters, 4 were article book chapters, 3 were article data papers, 2 were early access reviews, and 1 publication each was book review, retraction and review retracted.

Table 2. Curcuma Longa Research Publications on top 15 Prolific Countries in Terms of Citations, Number of Authors and h-index

\begin{tabular}{|c|c|c|c|c|c|c|c|c|c|c|c|c|}
\hline \multirow[b]{2}{*}{$\begin{array}{l}\text { S. } \\
\text { No }\end{array}$} & \multirow[b]{2}{*}{ Countries } & \multicolumn{3}{|c|}{ Number of Records } & \multicolumn{3}{|c|}{ Share of Records } & \multicolumn{3}{|c|}{ Citations } & \multirow{2}{*}{$\begin{array}{c}\text { NA } \\
2000- \\
2019\end{array}$} & \multirow{2}{*}{$\begin{array}{c}\text { HI } \\
2000- \\
2019\end{array}$} \\
\hline & & $\begin{array}{l}2000- \\
2009\end{array}$ & $\begin{array}{l}2010- \\
2019\end{array}$ & $\begin{array}{l}2000- \\
2019\end{array}$ & $\begin{array}{l}2000- \\
2009\end{array}$ & $\begin{array}{l}2010- \\
2019\end{array}$ & $\begin{array}{l}2000- \\
2019\end{array}$ & $\begin{array}{c}2000- \\
2009\end{array}$ & $\begin{array}{c}2010- \\
2019\end{array}$ & $\begin{array}{c}2000- \\
2019\end{array}$ & & \\
\hline 1 & India & 405 & 1097 & 1502 & 30.34 & 23.09 & 24.68 & 21212 & 15688 & 36900 & 6305 & 90 \\
\hline 2 & USA & 320 & 755 & 1075 & 23.97 & 15.89 & 17.66 & 42134 & 24856 & 66990 & 5896 & 125 \\
\hline 3 & Japan & 109 & 147 & 256 & 8.16 & 3.09 & 4.21 & 6871 & 2659 & 9530 & 1574 & 50 \\
\hline 4 & China & 86 & 659 & 745 & 6.44 & 13.87 & 12.24 & 5309 & 13906 & 19215 & 4933 & 64 \\
\hline 5 & $\begin{array}{l}\text { South } \\
\text { Korea }\end{array}$ & 72 & 264 & 336 & 5.39 & 5.56 & 5.52 & 4986 & 6229 & 11215 & 2023 & 54 \\
\hline 6 & Thailand & 68 & 170 & 238 & 5.09 & 3.58 & 3.91 & 2935 & 2598 & 5533 & 1048 & 39 \\
\hline 7 & UK & 50 & 107 & 157 & 3.75 & 2.25 & 2.58 & 6483 & 2469 & 8952 & 789 & 45 \\
\hline 8 & Brazil & 36 & 196 & 232 & 2.70 & 4.12 & 3.81 & 1589 & 2403 & 3992 & 1409 & 31 \\
\hline 9 & Taiwan & 31 & 96 & 127 & 2.32 & 2.02 & 2.09 & 3611 & 2042 & 5653 & 757 & 36 \\
\hline 10 & Germany & 29 & 88 & 117 & 2.17 & 1.85 & 1.92 & 1431 & 2736 & 4167 & 718 & 36 \\
\hline 11 & Italy & 29 & 172 & 201 & 2.17 & 3.62 & 3.30 & 3007 & 3945 & 6952 & 1330 & 44 \\
\hline 12 & Spain & 24 & 54 & 78 & 1.80 & 1.14 & 1.28 & 1847 & 1236 & 3083 & 452 & 31 \\
\hline 13 & Canada & 21 & 85 & 106 & 1.57 & 1.79 & 1.74 & 1871 & 2828 & 4699 & 574 & 38 \\
\hline 14 & Iran & 14 & 357 & 371 & 1.05 & 7.51 & 6.09 & 269 & 7491 & 7760 & 1792 & 47 \\
\hline \multirow[t]{2}{*}{15} & Egypt & 13 & 102 & 115 & 0.97 & 2.15 & 1.89 & 435 & 1364 & 1799 & 479 & 25 \\
\hline & Top 15 & 1307 & 4349 & 5656 & 97.90 & 91.52 & 92.92 & & & 196440 & & \\
\hline \multirow{2}{*}{\multicolumn{2}{|c|}{$\begin{array}{l}\text { Total world } \\
\text { Share of top } 15\end{array}$}} & 1335 & 4752 & 6087 & & & & & & 230621 & 30475 & - \\
\hline & & 97.90 & 91.52 & 92.92 & & & & & & 85.17 & & \\
\hline
\end{tabular}

NA- Number of Authors HI - h-index

It is inferred from the above table that the worldwide research output in the area of Curcuma longa research was initiated by as many as 106 countries throughout the world from 2000 to 2019, of which, 21 countries could produce single papers consistently in the 20 years of the study period. While 35 countries managed to record only 2-10 papers to their credit, 14 countries saw 11 to 20 paper publications, 12 countries had 21-50 papers, 7 countries saw 51-100 papers and 17 countries produced 101-1502 papers. The top most 15 prolific countries in Curcuma longa research produced varying number of publications ranging from 78 to 1502 during 2000-2019. The top 15 most productive countries in Curcuma longa research accounted for 92.92 percent of global 
publication share and 85.17 percent of citation share during the period of research (2000-2019). The first half of the research period (from 2000 to 2009) witnessed a total publication output of 1307 records in the total global publication share, which increased to 4752 records in the second 10 years of the research period (2010-2019).

Country-wise, the global publication share of top 15 countries varied widely from as low as 1.28 percent to as high as 24.68 percent during the study period of 2000-2019, with India accounting for the highest publication share of $(24.68 \%)$, followed by USA (17.66 \%), China (11.24 \% share), UK, Thailand, Japan and South Korea (from $2.58 \%$ to $5.52 \%$ ), Spain, Canada, Egypt, Germany, Taiwan, Brazil and Iran (from $1.28 \%$ to $6.09 \%$ ) between 2000 and 2019 .

Among the whole 106 countries which have research publications in Curcuma Longa to their credit, four countries Bosnia, Lithuania, Ukraine and Yemen are yet to start their citation score. Incidentally, these four countries have produced only one paper each, thereby explaining the reason for zero citation to their credit. While 17 countries among the total list received less than 10 citations, 42 countries managed to score more than 100 citations. Notably, 37 of them received citations between 100 and 1000 citations, while four countries USA (66987), India (36899), China (19214) and South Korea (11215) accounted for the highest number of citations during the study period.

Even though USA has only 1075 publication records to get the second position in the rank of topmost prolific countries, it has successfully gained the highest h-index on the global level in 2000-2019 followed by India (90), China (6) 4 and Japan (50). The remaining countries have gained only a low h-index below 50, exemplifying the minimum impact of their research publications on the global scenario.

It is clearly inferred from the above table that India stands out as the most prolific country from where highest number of research publications have originated, closely followed by the United States. Such an interest in this area of research can be explained by the fact that turmeric is widely cultivated and used in India for its medicinal, cooking and ritual purposes on a large scale. Notwithstanding the number of publication records, US top the citation score and H-Index.

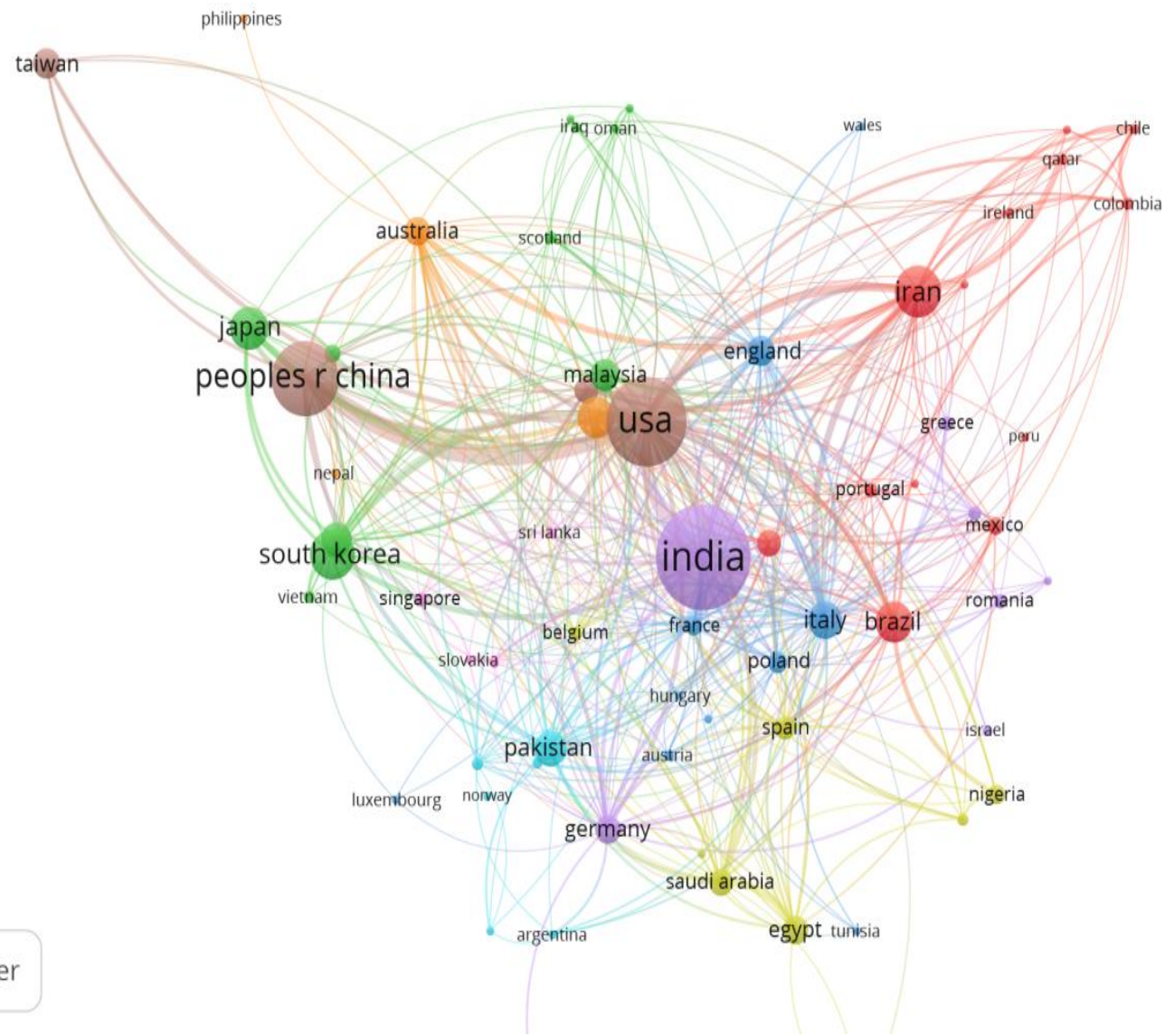

Figure 1. Bibliographic Coupling of Countries 
Table 3. Top 20 Most Prolific Authors in Field of Curcuma Longa Research Publications during 2000-2019

\begin{tabular}{|c|c|c|c|c|c|c|c|c|}
\hline $\begin{array}{l}\text { S. } \\
\text { No }\end{array}$ & Author & Institution & TR & TCS & CPP & HI & CR & CRPP \\
\hline 1 & Sahebkar A & $\begin{array}{l}\text { Mashhad University of Medical } \\
\text { Sciences, Mashhad, Iran. } \\
\text { University of Texas, MD Anderson }\end{array}$ & 73 & 3212 & 44 & 30 & 8555 & 117.19 \\
\hline 2 & Aggarwal BB & $\begin{array}{l}\text { Cancer Centre, Bio- immunotherapy, } \\
\text { USA }\end{array}$ & 67 & 21325 & 318.28 & 55 & 8696 & 129.79 \\
\hline 3 & Nayak S & $\begin{array}{l}\text { Siksha O Anusandhan University, } \\
\text { Centre for Biotechnology, Orissa, } \\
\text { India. }\end{array}$ & 35 & 300 & 8.57 & 11 & 1065 & 30.43 \\
\hline 4 & Kumar A & $\begin{array}{l}\text { Panjab Univ, Pharmaceutical Science, } \\
\text { Chandigarh, India }\end{array}$ & 33 & 2384 & 72.24 & 13 & 1671 & 5.64 \\
\hline 5 & $\mathrm{Li} \mathrm{Y}$ & $\begin{array}{l}\text { China Pharmaceutical University, } \\
\text { Pharmoclogy, Nanjing, Jiangsu, } \\
\text { Peoples R China. }\end{array}$ & 29 & 1152 & 39.72 & 18 & 1857 & 66.32 \\
\hline 6 & Liu Y & $\begin{array}{l}\text { University of Illinois, Dept Animal } \\
\text { Science, Urbana, USA. } \\
\text { Korea Basic Science Institute }\end{array}$ & 26 & 671 & 25.81 & 16 & 1151 & 44.27 \\
\hline 7 & Lee $\mathrm{J}$ & $\begin{array}{l}\text { Integrated Metabolic Research Group, } \\
\text { Seoul, South Korea. }\end{array}$ & 25 & 528 & 21.12 & 13 & 973 & 38.92 \\
\hline 8 & $\begin{array}{l}\text { Kunnumakkara } \\
\mathrm{AB}\end{array}$ & $\begin{array}{l}\text { University of Texas, MD Anderson } \\
\text { Cancer Centre, Houston, USA. }\end{array}$ & 23 & 8392 & 364.87 & 17 & 2857 & 124.22 \\
\hline 9 & Majeed M & $\begin{array}{l}\text { Sami Labs Ltd, Bangalore, Karnataka, } \\
\text { India. }\end{array}$ & 22 & 702 & 31.91 & 13 & 1851 & 84.14 \\
\hline 10 & Wang Y & $\begin{array}{l}\text { Fudan University, Pudong Medical } \\
\text { Centre, Shanghai, Peoples R China. } \\
\text { Siksha O Anusandhan University, }\end{array}$ & 22 & 510 & 23.18 & 14 & 866 & 39.36 \\
\hline 11 & Singh $S$ & $\begin{array}{l}\text { Centre for Biotechnology, Orissa, } \\
\text { India. } \\
\text { Siksha O Anusandhan University, }\end{array}$ & 21 & 169 & 8.05 & 7 & 879 & 41.86 \\
\hline 12 & Joshi RK & $\begin{array}{l}\text { Centre for Biotechnology, Orissa, } \\
\text { India. }\end{array}$ & 20 & 128 & 6.40 & 6 & 690 & 34.50 \\
\hline 13 & Li J & $\begin{array}{l}\text { Wenzhou Medical College, Zhejiang } \\
\text { Province, Peoples R China. } \\
\text { Peking University, Dept }\end{array}$ & 20 & 496 & 24.80 & 10 & 707 & 35.35 \\
\hline 14 & $\mathrm{Xu} \mathrm{Y}$ & $\begin{array}{l}\text { Pharmacology, Beijing, Peoples R } \\
\text { China. } \\
\text { Shandong University, School of }\end{array}$ & 19 & 1327 & 69.84 & 16 & 786 & 41.37 \\
\hline 15 & Zhang Y & $\begin{array}{l}\text { Pharmaceutical Science, Shandong, } \\
\text { Peoples R China. } \\
\text { China Medical University, Biological }\end{array}$ & 19 & 236 & 12.42 & 10 & 670 & 35.26 \\
\hline 16 & Chung JG & $\begin{array}{l}\text { Science \& Technology, Taichung, } \\
\text { Taiwan. }\end{array}$ & 18 & 761 & 42.28 & 13 & 673 & 37.39 \\
\hline 17 & Funk JL & $\begin{array}{l}\text { University of Arizona, Health Science } \\
\text { Centre, Tucson, USA. } \\
\text { USDA ARS, Animal Parasitic }\end{array}$ & 18 & 376 & 20.89 & 8 & 459 & 25.50 \\
\hline 18 & Lee $\mathrm{SH}$ & $\begin{array}{l}\text { Diseases Lab, Beltsville, MD } 20705 \\
\text { USA. } \\
\text { UNICAMP University, School of }\end{array}$ & 18 & 595 & 33.06 & 13 & 656 & 36.44 \\
\hline 19 & Meireles MAA & $\begin{array}{l}\text { Food Engineering, Campinas, SP, } \\
\text { Brazil. } \\
\text { Banaras Hindu University, Soil }\end{array}$ & 18 & 524 & 29.11 & 10 & 697 & 38.72 \\
\hline \multirow[t]{4}{*}{20} & Singh R & $\begin{array}{l}\text { Microbiology \& Eco-pathology Lab, } \\
\text { Uttar Pradesh, India. }\end{array}$ & 18 & 494 & 27.44 & 8 & 599 & 33.28 \\
\hline & & Top 20 authors & 544 & 44282 & 20.74 & & 36358 & \\
\hline & & Total output of Global & 20855 & 184708 & & & 273449 & \\
\hline & & $\begin{array}{l}\text { Share of top } 20 \text { authors in global total } \\
\text { output }\end{array}$ & 2.6 & 23.97 & & & 13.29 & \\
\hline
\end{tabular}


TR- Total Records TCS-Total Citation Scores CPP-Citation Per Paper HI - h-index CR- Cited Reference CRPP-Cited Reference Per Paper

The number of publication output varied from 73 to 18 among the top twenty most prolific authors listed in the above table in the field of Curcuma longa research during the total study period (2000-2019). These twenty most prolific authors have together contributed 544publication records on the global level, with a share of 2.6 percent research output to their credit. More significantly, these twenty most prolific authors have taken a huge share of 23.9 percent in citations, with a swapping citation score of 22566to their publications from 2000 to 2019. It is further inferred from the above table that these twenty most prolific authors produced 27.2 publications, received 2214.1 citations, attained 15.05 H-Index and received 1817.9 cited reference on the average during the total study period of twenty years.

Table 3 has presented sufficient information for arriving at the scientometric profile for each of these 20 most prolific authors. it is clear from the figure of individual publications of the first five most prolific authors that they have exceeded the group average score of 27.2 publications: Sahebkar A (74 publications) from Mashhad University of Medical Sciences, Iran; Aggarwal BB (67 publications) from University of Texas, United States of America; Nayak, S A. (35 publications) from Siksha O Anusandhan University, India and Li Y (29 publications) from China Pharmaceutical University, People's Republic of China during the study period. It is further revealed from the above table that four authors from among the top twenty most prolific list have received citation scores above the group average of 2214.1. The highest number of citations has been received by Aggarwal BB from University of Texas, USA, with a massive score of 21325. Kunnumakkara AB stands second in terms of citation score with 8392 citations, followed by Sahebkar with 3212 citations and Kumar A with 2384 citations during the study period.

A deep perusal of the individual profile of top twenty most prolific authors listed above further indicates that five authors have received their h-index above the group average of 15.05: Aggarwal BB (55), Sahebkar A (30), Li Y (18), Kunnumakkara AB (17) and Liu Y (16) during the study period. In addition, it is revealed that the first seven authors from among the top 20 group have received their cited reference above the group average of 1817.9. those authors who have received citation reference above the group average are Aggarwal BB (8696), Sahebkar A (8555), Kunnumakkara AB (2857), Li Y (1857), Majeed M (1851), Kumar A (1671) and Nayak S (1065) during the total study period.

A detailed analysis of the publication records in the field of curcuma Longa research between 2000 and 2019 reveals certain interesting information about the authorship pattern and proportion of publications in relation to their number of authorship. Such analysis brings out that a total of 20855 authors have contributed to the entire research output of 6087 publication records on Curcuma longa during the entire study period. Out of the total research output of 6087 publication records, as many as 3932 have been contributed by single author to five authors. It was followed by 1926 publication records contributed by six authors to ten authors, 206 publications by eleven authors to fifteen authors, 17 records by sixteen authors to twenty authors and 6 publication records contributed by twenty one to twenty six authors.

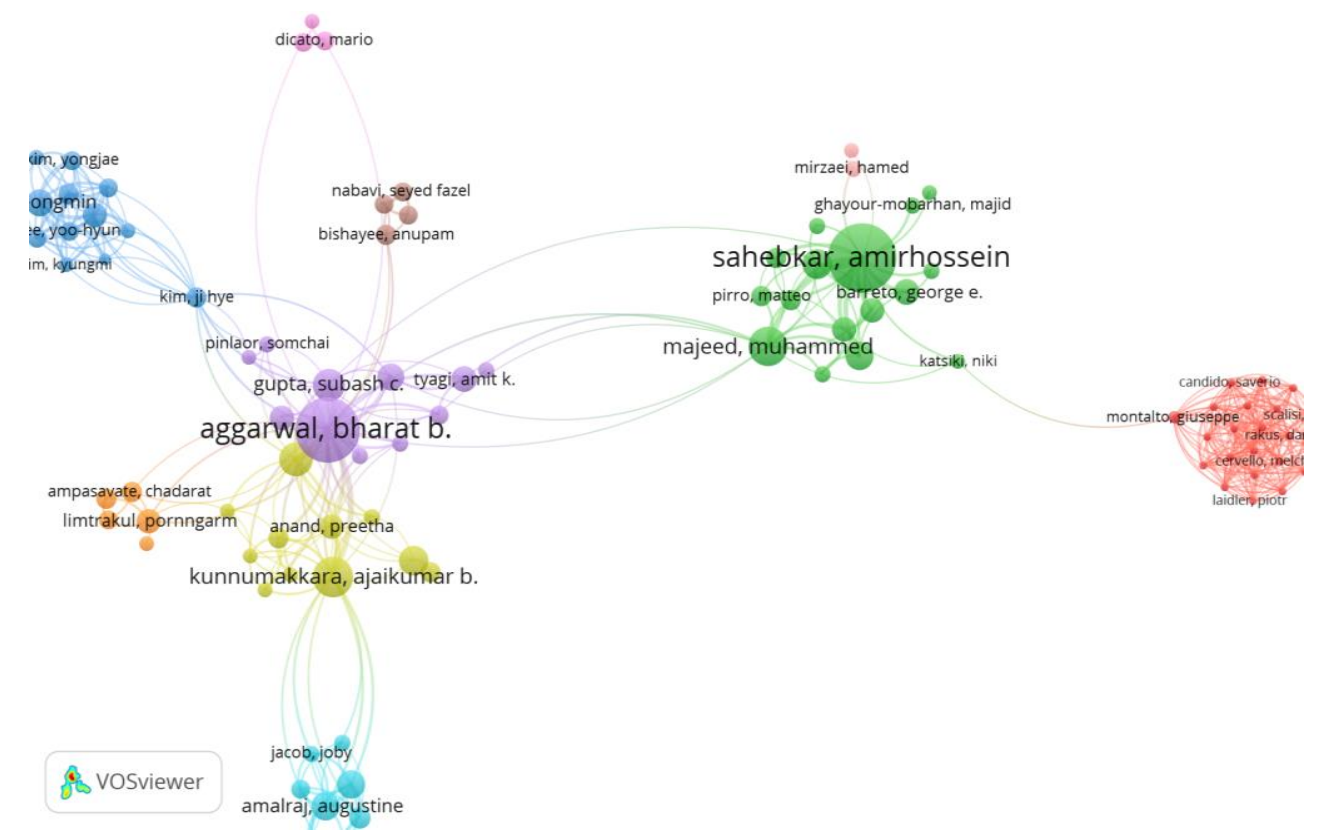


Figure 2. Bibliographic Coupling of Authors

Table 4. Most productive Global Institutions in the Field of Curcuma Longa (Turmeric) Research Output from 2000 to2019

\begin{tabular}{|c|c|c|c|c|c|c|c|c|}
\hline $\begin{array}{l}\text { S. } \\
\text { No }\end{array}$ & Institution & TR & TCS & CPP & NA & NAPP & HI & $\mathbf{C R}$ \\
\hline 1 & $\begin{array}{l}\text { Mashhad University of Medical Sciences, } \\
\text { Iran. }\end{array}$ & 107 & 3668 & 34.28 & 583 & 5.45 & 32 & 10500 \\
\hline 2 & $\begin{array}{l}\text { University of Texas, MD Anderson Cancer } \\
\text { Centre, USA. }\end{array}$ & 57 & 14703 & 257.95 & 299 & 5.25 & 44 & 6286 \\
\hline 3 & Islamic Azad University, Iran. & 55 & 684 & 12.44 & 236 & 4.29 & 13 & 2314 \\
\hline 4 & University Putra Malaysia, Malaysia. & 50 & 707 & 14.14 & 274 & 5.48 & 14 & 2558 \\
\hline 5 & Chiang Mai University, Thailand & 46 & 2190 & 47.61 & 222 & 4.83 & 19 & 1980 \\
\hline 6 & China Medical University, China & 46 & 1586 & 34.48 & 342 & 7.43 & 24 & 1974 \\
\hline 7 & Mahidol University, Thailand & 43 & 763 & 17.74 & 216 & 5.02 & 15 & 1233 \\
\hline 8 & $\begin{array}{l}\text { Centre for Food Technology and Research } \\
\text { Institute, Karnataka, India. }\end{array}$ & 42 & 2863 & 68.17 & 127 & 3.02 & 24 & 1847 \\
\hline 9 & Chulalongkorn University, Thailand & 42 & 1075 & 25.60 & 185 & 4.40 & 18 & 1519 \\
\hline 10 & University of Arizona, Tucson, USA. & 40 & 1182 & 29.55 & 222 & 5.55 & 19 & 1075 \\
\hline 11 & Seoul National University, South Korea & 39 & 3158 & 80.97 & 280 & 7.18 & 22 & 1814 \\
\hline 12 & University of Sao Paulo, Brazil & 38 & 553 & 14.55 & 229 & 6.03 & 14 & 1646 \\
\hline 13 & $\begin{array}{l}\text { Siksha O Anusandhan University, Orissa, } \\
\text { India }\end{array}$ & 37 & 301 & 8.14 & 175 & 4.73 & 11 & 1117 \\
\hline 14 & $\begin{array}{l}\text { Tehran University of Medical Sciences, } \\
\text { Iran }\end{array}$ & 36 & 578 & 16.06 & 229 & 6.36 & 13 & 2506 \\
\hline 15 & Rutgers State University, New Jersey, USA & 35 & 1178 & 33.66 & 269 & 7.69 & 16 & 1790 \\
\hline 16 & $\begin{array}{l}\text { Banaras Hindu University, Uttar Pradesh, } \\
\text { India }\end{array}$ & 32 & 845 & 26.41 & 159 & 4.97 & 15 & 2029 \\
\hline 17 & Chinese Academy of Sciences, China & 32 & 1257 & 39.28 & 217 & 6.78 & 21 & 1123 \\
\hline 18 & King Saud University, Saudi Arabia & 31 & 610 & 19.68 & 179 & 5.77 & 11 & 1683 \\
\hline 19 & $\begin{array}{l}\text { Shanghai Jiao Tong University, Shanghai, } \\
\text { China }\end{array}$ & 31 & 750 & 24.19 & 200 & 6.45 & 16 & 1831 \\
\hline \multirow[t]{3}{*}{20} & $\begin{array}{l}\text { Shenyang Pharmaceutical University, } \\
\text { Shenyang, China }\end{array}$ & 30 & 553 & 18.43 & 201 & 6.70 & 16 & 934 \\
\hline & Total of 20 Institutions & 869 & 39204 & \multirow[t]{2}{*}{41.17} & 4844 & \multirow[t]{2}{*}{5.67} & & $\begin{array}{l}47759 \\
273449\end{array}$ \\
\hline & $\begin{array}{l}\text { Total of Globe } \\
\text { Share of top } 20 \text { organizations in World }\end{array}$ & $\begin{array}{l}4879 \\
17.81\end{array}$ & $\begin{array}{l}184708 \\
21.22\end{array}$ & & $\begin{array}{l}30475 \\
15.89\end{array}$ & & & $\begin{array}{l}273449 \\
17.46\end{array}$ \\
\hline
\end{tabular}

TR-Total Records TCS-Total Citation Scores CPP-Citation Per Paper NA-Number of Authors NAPPNumber of Authors Per Paper HI- h-index CR-Cited Reference

A detailed scientometric review of top twenty institutions which produced more number of research publication output in the field of Curcuma Longa research during the entire study period of 2000-2019 has been presented in the above Table. The productivity of top 20 most prolific international institutions in the field of Curcuma longa Research varied from 30 to 107 publication records, and together these top twenty institutions have contributed 17.81 percent ( 869 publication records) in the total research output share on the global scenario during the total study period. In addition, these top twenty institutions have shared 32237 (20.75 percent) citation score, 4844 (15.89 percent) authors and 47759 (17.46 percent) cited reference during the study period of 20002019. It is also inferred from a detailed analysis of the above table that these top twenty institutions have the group average of 43.45publication records, 1960.1 citations, 242.2 authors and 2387.95 cited reference.

First six from among the top twenty institutions listed above have registered the publication output greater than the group average of 43.45. They are: Mashhad University of Medical Sciences, Iran (107 records), University of Texas, MD Anderson Cancer Center, USA (57 records), Islamic Azad University, Iran (55 records), University Putra Malaysia, Malaysia (50 publications), Chiang Mai University, Thailand (46 records) and China Medical University, China (46 records. Five from among these top twenty institutions have received Citation score greater than the group average of 1960.1 during the study period: MD Anderson Cancer Center, University of Texas, USA (14703), Mashhad University of Medical Sciences, Iran (3668), Seoul National University, South Korea (3158), Centre for Food Technology and Research Institute, Karnataka, India (2863) and Chiang Mai University, Thailand (2190). 
Six institutions have contributed authors above the group average of 242.2: Mashhad University of Medical Sciences, Iran (583 authors), China Medical University, China (342 authors), University of Texas, MD Anderson Cancer Centre (299 authors), Seoul National University, South Korea (280 authors), University Putra Malaysia, Malaysia (274 authors) and Rutgers State University, New Jersey (269 authors) during the total study period of 2000-2019. Four institutions have received cited references above the group average of 2387.95: Mashhad University of Medical Sciences, Iran (10500), University of Texas, MD Anderson Cancer Centre (6286), University Putra Malaysia, Malaysia (2558) and Tehran University of Medical Sciences, Iran (2506) during 2000-2019.

The h-index determines the quality of the research publications based on local and global citation scores. Among 4879 institutions which were found to have involved in research works relating to this field, only 6 gained more than $21 \mathrm{~h}$-index. MD Anderson Cancer Centre, University of Texas has gained 44 and stands first in this criterion, followed by Mashhad University of Medical Sciences, Iran with 32, China Medical University, China and Centre for Food Technology and Research Institute, Karnataka, India have gained 24 each, Seoul National University, South Korea has gained 22 and Chinese Academy of Sciences, China has gained 21 h-index respectively.

A total of 4879 institutions are found to have participated on the global scenario in the field of research on Curcuma longa during the study period of 2000-2019. Out of these total institutions, as many as 4452 institutions contributed one to five papers each to the field during the study period. It is also found that 216 institutions have produced six $t$ ten papers each, 89 institutions came out with eleven to fifteen papers, each, 40 institutions could contribute sixteen to twenty papers each, 21 institutions involved themselves in the publication of twenty one to twenty five papers each, 11 institutions contributed twenty six to thirty records each, 10 institutions have thirty one to thirty five publication records to each of their credit, and 6 institutions came out with forty one to fifty papers each. As a remarkable contribution of exceptional nature, four institutions have contributed from 51 to 107 papers each, as inferred from the analysis of publication records data for the study period.

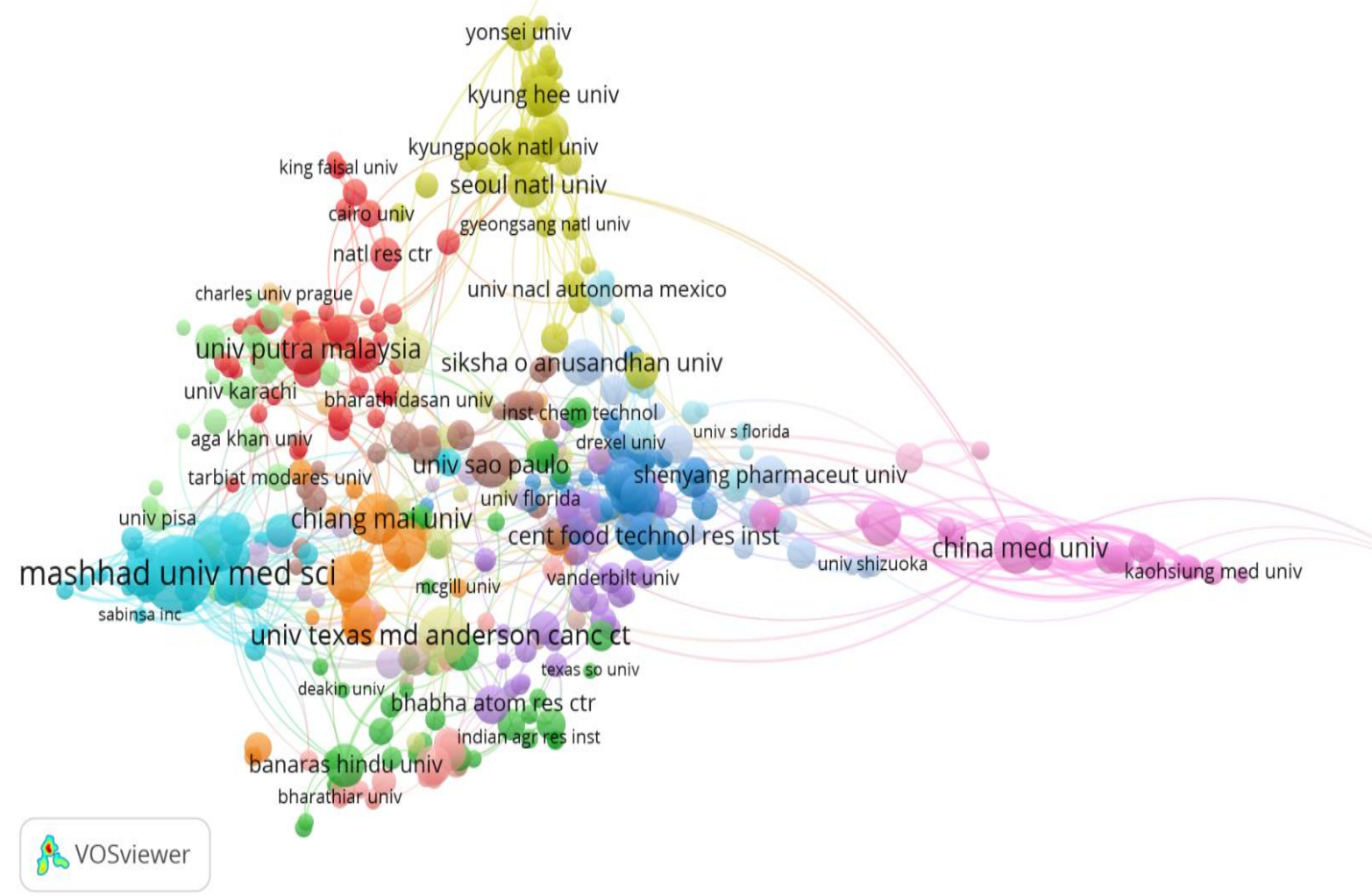

Figure 3. Bibliographic Coupling of Institutions 
Table 5. Top 20 Most Productive Journals in Curcuma Longa Research During 2000-2019

\begin{tabular}{|c|c|c|c|c|c|c|c|c|}
\hline \multirow[b]{2}{*}{$\begin{array}{l}\text { S. } \\
\text { No }\end{array}$} & \multirow[b]{2}{*}{ Journals } & \multirow[b]{2}{*}{ Publishers } & \multirow[b]{2}{*}{ Countries } & \multicolumn{3}{|c|}{ Number of Records } & \multirow[b]{2}{*}{ TCS } & \multirow[b]{2}{*}{$\mathbf{I F}$} \\
\hline & & & & $\begin{array}{l}2000- \\
2009\end{array}$ & $\begin{array}{l}2010- \\
2019\end{array}$ & $\begin{array}{l}2000- \\
2019\end{array}$ & & \\
\hline 1 & Food chemistry & Elsevier Ltd & Netherlands & 17 & 53 & 70 & 3639 & 6.306 \\
\hline 2 & $\begin{array}{l}\text { Journal of Agricultural } \\
\text { and Food Chemistry }\end{array}$ & $\begin{array}{l}\text { American } \\
\text { Chemical Society }\end{array}$ & USA & 34 & 35 & 69 & 4265 & 4.192 \\
\hline 3 & Phytotherapy Research & $\begin{array}{l}\text { John Wiley and } \\
\text { sons Ltd }\end{array}$ & $\begin{array}{l}\text { United } \\
\text { Kingdom }\end{array}$ & 14 & 49 & 63 & 2000 & 4.087 \\
\hline 4 & PLOS One & $\begin{array}{l}\text { Public Library of } \\
\text { Science }\end{array}$ & USA & - & 59 & 59 & 1993 & - \\
\hline 5 & $\begin{array}{l}\text { Journal of } \\
\text { Ethnopharmacology }\end{array}$ & $\begin{array}{l}\text { Elsevier Ireland } \\
\text { Ltd }\end{array}$ & Netherlands & 18 & 38 & 56 & 2194 & 3.690 \\
\hline 6 & Planta Medica & $\begin{array}{l}\text { Georg Thieme } \\
\text { Verlag }\end{array}$ & Germany & 22 & 29 & 51 & 1136 & 2.687 \\
\hline 7 & $\begin{array}{l}\text { International Journal of } \\
\text { Pharmaceutical } \\
\text { Sciences and Research }\end{array}$ & $\begin{array}{l}\text { Global Research } \\
\text { Online }\end{array}$ & India & - & 43 & 43 & 98 & 1.230 \\
\hline 8 & $\begin{array}{l}\text { Industrial Crops and } \\
\text { Products }\end{array}$ & Elsevier & Netherlands & 1 & 39 & 40 & 554 & 4.244 \\
\hline 9 & Molecules & $\begin{array}{l}\text { Multidisciplinary } \\
\text { Digital Publishing } \\
\text { Institute }\end{array}$ & Switzerland & 1 & 39 & 40 & 1773 & 3.267 \\
\hline 10 & Phytomedicine & $\begin{array}{l}\text { Urban und Fischer } \\
\text { Verlag Jena }\end{array}$ & Germany & 10 & 28 & 38 & 1358 & 4.268 \\
\hline 11 & $\begin{array}{l}\text { Evidence-Based } \\
\text { Complementary and } \\
\text { Alternative Medicine }\end{array}$ & $\begin{array}{l}\text { Hindawi } \\
\text { Publishing } \\
\text { Corporation }\end{array}$ & Egypt & 2 & 34 & 36 & 590 & 1.813 \\
\hline 12 & $\begin{array}{l}\text { Food and Chemical } \\
\text { Toxicology }\end{array}$ & Elsevier & Netherlands & 11 & 23 & 34 & 2242 & 4.679 \\
\hline 13 & $\begin{array}{l}\text { Journal of Food } \\
\text { Science and } \\
\text { Technology-Mysore }\end{array}$ & & & 13 & 20 & 33 & 223 & - \\
\hline 14 & Nutrients & $\begin{array}{l}\text { Multidisciplinary } \\
\text { Digital Publishing } \\
\text { Institute }\end{array}$ & Switzerland & - & 31 & 31 & 543 & 4.546 \\
\hline 15 & Biofactors & Wiley Blackwell & USA & 5 & 24 & 29 & 1757 & 4.734 \\
\hline 16 & $\begin{array}{l}\text { Journal of Functional } \\
\text { Foods }\end{array}$ & Elsevier Ltd. & $\begin{array}{l}\text { United } \\
\text { Kingdom }\end{array}$ & - & 29 & 29 & 1113 & 2.985 \\
\hline 17 & $\begin{array}{l}\text { Biochemical and } \\
\text { Biophysical Research } \\
\text { Communications }\end{array}$ & $\begin{array}{l}\text { Academic Press } \\
\text { Inc. }\end{array}$ & USA & 15 & 13 & 28 & 1723 & 4.653 \\
\hline 18 & $\begin{array}{l}\text { Molecular Nutrition \& } \\
\text { Food Research }\end{array}$ & $\begin{array}{l}\text { Wiley-VCH } \\
\text { Verlag }\end{array}$ & $\begin{array}{l}\text { United } \\
\text { Kingdom }\end{array}$ & 7 & 21 & 28 & 1853 & \\
\hline 19 & Food \& Function & $\begin{array}{l}\text { Royal society of } \\
\text { Chemistry }\end{array}$ & $\begin{array}{l}\text { United } \\
\text { Kingdom }\end{array}$ & - & 25 & 25 & 491 & 4.171 \\
\hline 20 & $\begin{array}{l}\text { Indian Journal of } \\
\text { Agricultural Sciences }\end{array}$ & $\begin{array}{l}\text { Indian Council of } \\
\text { Agricultural } \\
\text { Research }\end{array}$ & India & 8 & 17 & 25 & 38 & 0.290 \\
\hline Tot & of 20 journals & & & 178 & 649 & 827 & 29583 & 61.842 \\
\hline $\begin{array}{l}\text { Tot: } \\
\text { Sha }\end{array}$ & $\begin{array}{l}\text { Global output } \\
\text { ef } 20 \text { journals in Global }\end{array}$ & output & & $\begin{array}{l}1335 \\
13.33\end{array}$ & $\begin{array}{l}4752 \\
13.65\end{array}$ & $\begin{array}{l}6087 \\
13.49\end{array}$ & $\begin{array}{l}184708 \\
16.01\end{array}$ & \\
\hline
\end{tabular}


As inferred from the analysis, the total of 6087 records were published by 2005 journals, of which 1783 journals published 1-5 papers each, 111 journals published 6-10 papers each, 71 journals published 11-20 papers each, 25 journals published 21-25 papers each, 11 journals published 26-50 papers each and 6 journals published 51-70 papers each during the entire study period of 2000-2019. The top 20 most productive journals account 25 to 70 papers each on Curcuma longa research; together they accounted for 13.49 percent ( 827 papers) share of total Curcuma longa output published in journals during 2000-2019. Curcuma longa research being accounted increasingly in journals is steadily becoming a trend; the top 20 most productive journals output in first half years of 2000-2009 has shown decline 13.33 percent and second half of 2010-2019 has shown increasing 13.65 percent.

Six journals have published more than 50 papers during the study period of 2000-2019. The journal Food Chemistry from Elsevier Ltd, Netherlands published 70 papers, Journal of Agricultural and Food Chemistry from American Chemical Society, USA published 69 papers, Phytotherapy Research, John Wiley and sons Ltd, United Kingdom came out with 63 papers, PLOS One, Public Library of Science, USA published 59 papers, Journal of Ethno pharmacology, Elsevier Ireland Ltd, Netherlands published 56 papers and Planta Medica, Georg Thieme Verlag, Germany published 51 papers during the study period.

Ten journals have gained their citation score above the group average of 1479.15: Food chemistry tops the list of journals with highest number of citations with 3639, followed by the Journal of Agricultural and Food Chemistry (4265), Phytotherapy Research (2000), PLOS One (1993), Journal of Ethnopharmacology (2194), Molecules (1773), Food and Chemical Toxicology (2242), Biofactors (1757), Biochemical and Biophysical Research Communications (1723) and Molecular Nutrition \& Food Research (1853) during the study period of 2000-2019.

The quality of a journal is measured by the Impact Factor. It is a calculation of the frequency in which the articles published in a journal are cited during a given point of time. It is used to assess the significance and rank of a journal by calculating the frequency in which particular articles are cited. The calculation depends on a time period of two years and involves dividing the number of cited publications by the number of records that are citable. Impact factor calculated using Journal Citation Reports (JCR) published by Clarivate Analytics in the 2020 edition provides the combination of impact and influence metrics from Web of Science database in the years 2019.

A total of eleven journals have received the h-index above the group average of 3.092: Food Chemistry (6.306), Journal of Agricultural and Food Chemistry (4.192), Phototherapy Research (4.087), Journal of Ethnopharmacology (3.690), Industrial Crops and Products (4.244), Molecules (3.267), Phytomedicine (4.268), Food and Chemical Toxicology (4.679), Nutrients4.546), Biofactors (4.734), Biochemical and Biophysical Research Communications (4.653) and Food \& Function (4.171) during the study period.

Table 6. Curcuma longa Research Publications in Top 20 Conferences During 2000-2019

\begin{tabular}{|c|c|c|c|}
\hline $\begin{array}{l}\text { S. } \\
\text { No }\end{array}$ & Conference titles & $\begin{array}{l}\text { Date, Place and } \\
\text { Country }\end{array}$ & Records \\
\hline 1 & $3^{\text {rd }}$ World Congress on Medicinal and Aromatic Plants - WOCMAP III & $\begin{array}{l}\text { 3-7, February 2003, } \\
\text { Chiang Mai, } \\
\text { Thailand }\end{array}$ & 6 \\
\hline & & $\begin{array}{l}\text { 21-25, April 2018; } \\
02-06\end{array}$ & \\
\hline 2 & Annual Experimental Biology Meeting & $\begin{array}{l}\text { April 2016; 21-25, } \\
\text { April 2012, San } \\
\text { Diego, USA }\end{array}$ & 5 \\
\hline & $2^{\text {nd }}$ Southeast Asia Symposium on Quality Management in Postharvest & 04-06, December & \\
\hline 3 & Systems & $\begin{array}{l}2013, \\
\text { Vientiane, Laos. }\end{array}$ & 4 \\
\hline 4 & $\begin{array}{l}55^{\text {th }} \text { International Congress and Annual Meeting of the Society for } \\
\text { Medicinal Plant Research and Natural Product Research }\end{array}$ & $\begin{array}{l}\text { 16-20, August 2009, } \\
\text { Geneva, } \\
\text { Switzerland }\end{array}$ & 4 \\
\hline 5 & Annual Conference of the American Society for Horticultural Science & $\begin{array}{l}\text { 22-25, July } 2019 \text {, } \\
\text { Las Vegas, Laos. }\end{array}$ & 4 \\
\hline 6 & International Symposium on Medicinal and Nutraceutical Plants & 25-29, November & 4 \\
\hline
\end{tabular}


$1^{\text {st }}$ Annual Applied Science and Engineering Conference - AASEC

8

$1^{\text {ST }}$ International Conference of Animal Science and Technology ICAST

$248^{\text {th }}$ National Meeting of the American Chemical Society - ACS 9

$5^{\text {th }}$ International Conference on Advanced Engineering and Technology

- ICAET

$7^{\text {th }}$ Joint Meeting of the Association Francophone pour l'Enseignement de la Recherché enPharmacognosie (AFERP), American Society of

Pharmacognosy (ASP), Society for Medicinal Plant Research (GA),

Photochemical Society of Europe (PSE), and Societal Italian

Fitochimica (SIF)

Annual Meeting of the American Society for Pharmacology and

Digestive Disease Week - DDW

International Congress on Natural Products Research on Global Change

Natural Products and Human Health, $8^{\text {th }}$ Joint Meeting of AFERP ASP GA PSE AND SIF

International Symposium on Underutilized Plants for Food Security Nutrition Income and Sustainable Development

10th Asian Congress of Nutrition

$11^{\text {th }}$ International Biorelated Polymer Symposium / 243rd National

Spring Meeting of the American-Chemical-Society (ACS)

$12^{\text {th }}$ International Scientific Conference on Animal Physiology

$12^{\text {th }}$ Joint Conference on Chemistry (JCC)

19

1st International Conference on Natural Products and Molecular
2009 ,

Newdelhi, India

18, November 2016,

Bandung, Indonesia

6 - 7, November

2018,

Makassar,

Indonesia

10-14, August

2014,

San Francisco,

USA

14-16, December

2018,

Inchon, South

Korea.

3-8, August 2008 ,

Athens, Greece.

22-26, April 2017,

Chicago, Illinois,

USA

18-21, May 2019

San Diego,

California, USA

28 July - 1 August

2012,

New York, USA

31, January 2009,

Arusha, Tanzania

September 2007,

Taipei, Taiwan

25-29, March 2012,

San Diego, CA,

USA

13-15, June 2016,

Boretice, Czech

Republic

19-20,September

2017,

Semarang,

Indonesia

13-15, January

2005,

Cape Town, South 
A conference is usually understood as a summit consisting of a large number of people to talk about thorough issues of relevance and interest. It is a formal meeting of shared interest, naturally one that takes place over one or few days. Any research conference provides a chance to meet the people thinking in one particular area in order to conduct serious discussions and come out with the new theme. In this line, the above table deals with the conferences on Curcuma longa research for the period of twenty years from 2000 to 2019.

Out of the total number of top 100 conferences, 6 conferences led to the publication of four to six papers, ten of them resulted in 3 papers each, 35 of them produced 2 papers each, and the remaining 56 conferences provided one paper each. Among the top 20 conferences, the highest conferences held in the country of USA (6) followed by Indonesia (3) and Laos (2). The countries South Africa, Czech Republic, South Korea, Taiwan, Switzerland, Greece, Tanzania, India and Thailand were found to have held each one conference during this period.

The highest number of publication record (6) was published from the conference of third World Congress on Medicinal and Aromatic Plants held in February 3 to 7 in 2003 at Chiang Mai, Thailand followed by five records published in the conferences of Annual Experimental Biology Meeting held in 21 to 25, April 2018; 02 to 06, April 2016 and 21 to 25 April 2012 at San Diego, USA respectively.

Each four record was published in four conferences, $2^{\text {nd }}$ Southeast Asia Symposium on Quality Management in Postharvest Systems held at Vientiane in December 2013; 55 $5^{\text {th }}$ International Congress and Annual Meeting of the Society for Medicinal Plant Research and Natural Product Research held at Geneva, Switzerland held in August 2009; Annual Conference of the American Society for Horticultural Science held at Las Vegas, Laos in July 2019 and International Symposium on Medicinal and Nutraceutical Plants held at Newdelhi, India in November 2009 respectively.

Table 7. Contribution of Funding Agencies to the Curcuma Longa Research Publications During 2000-2019

\begin{tabular}{llll}
\hline $\begin{array}{c}\text { S. } \\
\text { No }\end{array}$ & \multicolumn{1}{c}{ Name of the Funding Agencies } & Records & Country \\
\hline 1 & National Natural Science Foundation of China (NSFC) & 318 & China \\
2 & United States Department of Health \& Human Services & 304 & USA \\
3 & Council of Scientific Industrial Research, CSIR. & 99 & India \\
4 & Department of Science Technology- DST. & 87 & India \\
5 & National Council for Scientific and Technological Development - CNPQ & 83 & Brazil \\
6 & Ministry of Education Culture Sports Science and Technology - MEXT & 75 & Japan \\
7 & CAPES, Federal Agency for Post-Graduate Education & 68 & Brazil \\
8 & United States Department of Health \& Human Services, National Cancer & 64 & USA \\
& Institute, & 59 & India \\
9 & Department of Biotechnology -DBT & 46 & Taiwan \\
10 & National Science Council of Taiwan & 43 & India \\
11 & Indian Council of Medical Research, ICMR & 42 & Thailand \\
12 & Thailand Research Fund - TRF & 37 & Japan \\
13 & Japan Society for the Promotion of Science & 33 & South \\
14 & Ministry of Education, Science and Technology, Republic of Korea & & Korea \\
& $\quad$ & 28 & Europe \\
15 & European Union & 27 & USA \\
16 & Department of Health \& Human Services & 24 & China \\
17 & National Basic Science of China & 20 & China \\
18 & China Postdoctoral Science Foundation & 20 & Thailand \\
19 & Chulalongkorn University & 20 & Canada \\
20 & Natural Sciences and Engineering Research Council of Canada & & \\
\hline
\end{tabular}

Public or private organizations offering finance support to prepare research work on individual or group of researchers based on the laboratories and produced research papers are termed as 'funding agencies'. Most of the countries in the world have got funding agencies aimed at disseminating research funds to find out solutions to the current problems like medical, agriculture technology issues. A few of the research works especially in the fields of science, technology and engineering are dependent on full funding from such agencies since research works in these fields are more often than not very expensive and no time limit can be stipulated. As shown in the above table, these twenty organizations from different countries of the world have topped the list of funders for research works in the field of Curcuma longa. 
Among these top twenty organizations, as many as four funding organizations from India offered research funding on curcuma longa research from 2000 to 2019. Three funding organizations each from China and USA, two funding agencies each from Brazil, Thailand and Japan, and the remaining countries including Taiwan, Europe, Canada and Korea had each one funding organization to provide for financial assistance in this field of research. Seven agencies funded research papers between 50 and 100, remaining eleven agencies funded between 20 and 50 papers. The highest papers 318 and 304 were funded by National Natural Science Foundation of China (NSFC) and United States Department of Health \& Human Services (USA). The funding agencies from India include Council of Scientific Industrial Research (CSIR), Department of Science Technology (DST), Department of Biotechnology (DBT) and Indian Council of Medical Research (ICMR), which have funded for 99, 87, 59 and 43 research papers respectively.

Brazil funded through its State agency of National Council for Scientific and Technological Development (68), Taiwan from the agency National Science Council of Taiwan (46), Thailand from Thailand Research Fund (42), Japan from Japan Society for the Promotion of Science (37), South Korea through Ministry of Education, Science and Technology, Republic of Korea (33). The European countries funded through the organization European Union (28), USA from Department of Health \& Human Services (27), China from National Basic Science of China (24) and China Postdoctoral Science Foundation (20), Thailand from Chulalongkorn University (20) and Canada from Natural Sciences and Engineering Research Council of Canada (20).

Table 8. Time Series Analysis of Curcuma Longa Research Publications

\begin{tabular}{|c|c|c|c|c|c|}
\hline S. $\mathrm{N}$ & Years & Records (Y) & $\mathbf{X}$ & $X^{2}$ & XY \\
\hline 1. & 2000 & 58 & -10 & 100 & $0-580$ \\
\hline 2. & 2001 & 55 & -9 & 81 & -495 \\
\hline 3. & 2002 & 68 & -8 & 64 & -544 \\
\hline 4. & 2003 & 83 & -7 & 49 & -581 \\
\hline 5. & 2004 & 92 & -6 & 36 & -552 \\
\hline 6. & 2005 & 130 & -5 & 25 & -650 \\
\hline 7. & 2006 & 157 & -4 & 16 & -628 \\
\hline 8. & 2007 & 198 & -3 & 9 & -594 \\
\hline 9. & 2008 & 218 & -2 & 4 & -436 \\
\hline 10. & 2009 & 276 & -1 & 1 & -276 \\
\hline 11. & 2010 & 296 & 1 & 1 & 296 \\
\hline 12. & 2011 & 311 & 2 & 4 & 622 \\
\hline 13. & 2012 & 354 & 3 & 9 & 1062 \\
\hline 14. & 2013 & 435 & 4 & 16 & 1740 \\
\hline 15. & 2014 & 398 & 5 & 25 & 1990 \\
\hline 16. & 2015 & 491 & 6 & 36 & 2946 \\
\hline 17. & 2016 & 512 & 7 & 49 & 3584 \\
\hline 18. & 2017 & 573 & 8 & 64 & 4584 \\
\hline & 2018 & 680 & 9 & 81 & 6120 \\
\hline 20. & 2019 & 702 & 10 & & 7020 \\
\hline Tota & & 6087 & & & 24628 \\
\hline
\end{tabular}

Straight line equation has been applied to arrive at projections for expectations growth under Time Series analysis.

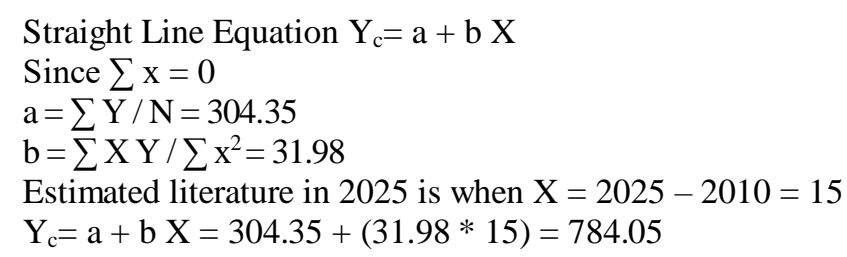

Estimated literature in 2030 is when $X=2030-2010=20$

$=304.35+(31.98 * 20)=\mathbf{9 4 3 . 9 5}$

Based on the application of the formula of Time Series Analysis, the results have been obtained separately for the years 2025 and 2030. It is predicted that the future trend of growth rate in Turmeric Research Literature output may incline as the present scenario reveals an increasing trend. The assumption is that there is a positive growth level in productivity of Turmeric Research Literatures. 
Table 9. Highly Cited Papers in the Field of Curcuma Longa Research During 2000-2019

\begin{tabular}{|c|c|c|c|c|}
\hline S. No & Name of the Papers & Authors & Bibliography & Citations \\
\hline 1 & $\begin{array}{l}\text { Bioavailability of curcumin: } \\
\text { Problems and Promises }\end{array}$ & $\begin{array}{l}\text { Preetha Anand, Ajaikumar } \\
\text { B Kunnumakkara, Robert } \\
\text { A Newman, et al. }\end{array}$ & $\begin{array}{l}\text { Molecular Pharmaceutics, } \\
\text { Vol.4; Iss.6 ; Nov-Dec } \\
2007\end{array}$ & 2687 \\
\hline 2 & $\begin{array}{l}\text { Anticancer potential of curcumin: } \\
\text { Preclinical and clinical studies }\end{array}$ & $\begin{array}{l}\text { BB Aggarwal, A Kumar, } \\
\text { AC Bharti }\end{array}$ & $\begin{array}{l}\text { Anticancer Research, } \\
\text { Vol.23;Iss. 1A; pp 363-398; } \\
\text { Jan-Feb } 2003\end{array}$ & 1793 \\
\hline 3 & $\begin{array}{l}\text { Phase I clinical trial of curcumin, a } \\
\text { chemo preventive agent, in patients } \\
\text { with high-risk or pre-malignant } \\
\text { lesions }\end{array}$ & $\begin{array}{l}\text { AL Cheng, CH Hsu, JK } \\
\text { Lin etal. }\end{array}$ & $\begin{array}{l}\text { Anticancer Research, } \\
\text { Vol.21; Iss. 4B; pp 2895- } \\
\text { 2900; Jul-Aug } 2001\end{array}$ & 1430 \\
\hline 4 & $\begin{array}{l}\text { Curcumin as "Curecumin": From } \\
\text { kitchen to clinic }\end{array}$ & $\begin{array}{l}\text { Ajay Goel, Ajaikumar B } \\
\text { Kunnumakkara, Bharat B } \\
\text { Aggarwal }\end{array}$ & $\begin{array}{l}\text { Biochemical } \\
\text { Pharmacology, Vol.75; } \\
\text { Iss.4; pp 787-809; Feb } 15 \\
2008\end{array}$ & 1251 \\
\hline 5 & $\begin{array}{l}\text { Molecular targets of dietary agents } \\
\text { for prevention and therapy of cancer }\end{array}$ & BB Aggarwal, S Shishodia & $\begin{array}{l}\text { Biochemical } \\
\text { Pharmacology, Vol.71; } \\
\text { Iss. } 10 \text {; pp 1397-1421; } \\
\text { May 14, } 2006\end{array}$ & 1178 \\
\hline 6 & $\begin{array}{l}\text { Molecular mechanisms underlying } \\
\text { chemo preventive activities of anti- } \\
\text { inflammatory phytochemicals: } \\
\text { down-regulation of COX-2 and } \\
\text { iNOS through suppression of NF- } \\
\text { kappa B activation }\end{array}$ & $\begin{array}{l}\text { YJ Surh, KS Chun, HH } \\
\text { Cha etal. }\end{array}$ & $\begin{array}{l}\text { Mutation Research- } \\
\text { fundamental and Molecular } \\
\text { Mechanisms of } \\
\text { Mutagenesis, Vol.480; } \\
\text { Iss.SI : pp 243-268 ; Sep 1, } \\
2001\end{array}$ & 1156 \\
\hline 7 & $\begin{array}{l}\text { Curcumin: From ancient medicine } \\
\text { to current clinical trials }\end{array}$ & $\begin{array}{l}\text { H Hatcher, R Planalp, J } \\
\text { Cho etal. }\end{array}$ & $\begin{array}{l}\text { Cellular and molecular life } \\
\text { sciences. Vol.65; Iss. } 11 ; \text { pp } \\
\text { 1631-1652; June } 2008\end{array}$ & 1077 \\
\hline 8 & $\begin{array}{l}\text { Multiple biological activities of } \\
\text { curcumin: A short review }\end{array}$ & $\begin{array}{l}\text { RK Maheshwari, AK } \\
\text { Sing, J Gaddipatietal. }\end{array}$ & $\begin{array}{l}\text { Life Sciences. Vol.78; } \\
\text { Iss. } 18 ; \text { pp 2081-2087, Mar. } \\
272006 .\end{array}$ & 1071 \\
\hline 9 & Curcumin: The story so far & $\begin{array}{l}\text { RA Sharma, AJ Gescher, } \\
\text { WP Steward }\end{array}$ & $\begin{array}{l}\text { European Journal of } \\
\text { Cancer. } \\
\text { Vo.41; Iss.13; pp 1955- } \\
\text { 1968; } \\
\text { Sep 2005. }\end{array}$ & 1037 \\
\hline 10 & $\begin{array}{l}\text { The curry spice curcumin reduces } \\
\text { oxidative damage and amyloid } \\
\text { pathology in an Alzheimer } \\
\text { transgenic mouse }\end{array}$ & $\begin{array}{l}\text { GP Lim, T Chu, FS Yang } \\
\text { etal. }\end{array}$ & $\begin{array}{l}\text { Journal of Neuroscience. } \\
\text { Vol.21; Iss. } 21 \text {; pp 8370- } \\
8377 \text {; Nov. } 12001\end{array}$ & 1031 \\
\hline 11 & $\begin{array}{l}\text { Potential therapeutic effects of } \\
\text { curcumin, the anti inflammatory } \\
\text { agent, against neurodegenerative, } \\
\text { cardiovascular, pulmonary, } \\
\text { metabolic, autoimmune and } \\
\text { neoplastic diseases }\end{array}$ & $\begin{array}{l}\text { Bharat B Aggarwal, } \\
\text { Kuzhuvelil B Harikumar }\end{array}$ & $\begin{array}{l}\text { International Journal of } \\
\text { Biochemistry \& Cell } \\
\text { Biology. Vol. 41; Iss.1; pp } \\
\text { 40-59; Jan. 2009 }\end{array}$ & 953 \\
\hline 12 & Curcumin: The Indian solid gold & $\begin{array}{l}\text { Bharat B Aggarwal, Chitra } \\
\text { Sundaram, Nikita Malani } \\
\text { et al. }\end{array}$ & $\begin{array}{l}\text { Molecular Targets and } \\
\text { Therapeutic Uses of } \\
\text { Curcumin in Health and } \\
\text { Disease }\end{array}$ & 926 \\
\hline 13 & $\begin{array}{l}\text { Antioxidant and radical scavenging } \\
\text { properties of curcumin }\end{array}$ & AK Tuba, Ithami Gulcin & $\begin{array}{l}\text { Chemico-Biological } \\
\text { Interactions. Vol.174; Iss.1 } \\
\text {; pp 27-37; July } 102008\end{array}$ & 858 \\
\hline 14 & $\begin{array}{l}\text { Biological activities of curcumin } \\
\text { and its analogues (Congeners) made } \\
\text { by man and mother nature }\end{array}$ & $\begin{array}{l}\text { Preetha Anand, Sherin G } \\
\text { Thomas, Ajaikumar B } \\
\text { Kunnumakkkara et al }\end{array}$ & $\begin{array}{l}\text { Chemical Pharmacology. } \\
\text { Vol. 76; Iss.11; SI, pp } \\
\text { 1590-1611; Dec12008 }\end{array}$ & 736 \\
\hline 15 & $\begin{array}{l}\text { Therapeutic roles of curcumin: } \\
\text { Lessons Learned from Clinical } \\
\text { Trials }\end{array}$ & $\begin{array}{l}\text { Subash C Gupta, } \\
\text { Sridevipatchva, } \\
\text { Bharat B Aggarwal }\end{array}$ & $\begin{array}{l}\text { AAPS Journal. Vol. 15; } \\
\text { Iss.1; pp 195-218; Jan } 2013\end{array}$ & \\
\hline
\end{tabular}

Citation plays a vital role in any research publication; a citation includes research documents published by single, double or group of authors based on intense laboratory works. The language of English and the open access publications play a key role in reaching out to the maximum of users. Qualities of the papers are measured only in terms of citations they have received in local and global levels. Highly cited papers in the field of curcuma longa research were identified by using Times cited column in Web of Science home page. It shows the received and updated citation score for each research publication. A total of 4,957 papers were found to have received citations during the study period of twenty years from 2000 to 2019. There are 10 papers which received heist number of citations between 1001 and 2687, followed by 19 papers that received between 501 and 1000 citations, 38 papers received between 301 and 500 papers, 65 papers received between 201 and 300, 242 
papers received between 101 and 200 citations, 526 papers were received between 51-100 citations and 4057 papers received between 1 and 50 citations. The remaining papers in the total publication records on curcuma longa research are not received single citations.

In the study period of past twenty years from 2000 to 2019 in Curcuma longa Research publications, the highest citation of 2687 was received by the paper 'Bioavailability of curcumin: Problems and Promises' Preetha Anand, Ajaikumar B Kunnumakkara, Robert A Newman, etal. Published by the authors in the journal of 'Molecular Pharmaceutics', Vol.4; Iss.6; Nov-Dec 2007 followed by the authors BB Aggarwal, A Kumar, AC Bharti in the title of 'Anticancer potential of curcumin: Preclinical and clinical studies' from the journal Anticancer Research, Vol.23; Iss. 1A; pp 363-398; Jan-Feb 2003 received 1793 citations and AL Cheng, CH Hsu, JK Lin etal. Published in the paper 'Phase I clinical trial of curcumin, a chemo preventive agent, in patients with high-risk or pre-malignant lesions' from the journal Anticancer Research, Vol.21; Iss. 4B; pp 2895-2900; Jul-Aug 2001 received 1430 citations respectively.

This study has been conducted for a time period of twenty years. Such an extended time period has been stipulated for this study in order to arrive at a holistic picture of the research trends in the particular field. The findings based on such a holistic analysis is intended to help the researchers, both with experienced and in their early career, to get a clear map of research.

\section{Language of Publications}

The total records consisting of 6087 publications were authored in 18 different languages, among which English has, quite naturally for the present scenario, emerges to be the predominant language. A swapping 98.8 percent of the records were published in English language, whereas the other 17 languages together have only 1.2 percent of publications to their credit. Next to the English language, 17 papers got published in Portuguese language, followed by eight papers in Indonesian, seven papers each in Japanese and Spanish languages, six papers in German language. Four papers each were published in Chinese and Turkish, Three papers in Polish and two papers each were authored in Korean, Russian and Thai languages. One paper each was published in Czech, French, Hungarian, Italian, Malay and Persian languages.

\section{Usage of Words}

The entire corpus of publication records in the chosen field of study for the study period contained 59644 words matching the keyword search. The word Curcumin was found to have been used in 2435 papers, followed by the word 'Turmeric' used in 1302 papers. While the keyword 'Curcuma' was found in 1219 records, 'longa' was found used in 1007 papers. Some medical terms like Cancer (468), antioxidant (258) and curcuminoids (254) were also found to have been used in the publication records.

\section{VoS Viewer}

VOS Viewer was developed by Nees Jan Van Eck and Ludo Waltman, Centre for Science and Technology Studies, Leiden University. It will give the picture of network visualization, Overlay visualization and Density visualization. There are three types of maps created based on network data, bibliographic data and text data. The supported file types are Web of Science, Scopus, Dimensions and pubmed. Here we have used bibliographic data files and create map bibliographic coupling of authors, countries and organizations.

\section{Conclusion}

This study has been carried out by involving scientometric analysis methods in the field of Curcuma longa research published and indexed in past 20 years from 2000 to 2019. The major outcome of this study is the segregation of publication records for the study period in the chosen field of research in terms of document types, countries, journals, authors and research institutions with highest number of publications, preferred medium of publication, growth ratio during the twenty years of study period, contribution of funding agencies and role of conferences held in this field.

For this research, the software Histcite and VoS viewer were optimally used so as to derive a more complete picture of the research. The Histcite software was utilized for preparing the tables in the order of annual growth of publications, authorship, organizations, journals and measured citations. Likewise, a graphical picture of bibliographic coupling of authors, institutions and countries in networked references was performed through the VoS viewer. 
While mapping out the quality of publication records by measuring citations based on local and global index scores, the study has also provided valuable information on citations through the papers on curcuma longa research including total number of citations, average citation score and Hirsch-index. A total of 6807 papers received $1,84,708$ citations and the h-index was found to be at 171 during this study period.

The highest number of research works were published in the year 2019 (702) and the lowest number of publication was (55) recorded in the year 2001. The first fifteen countries contributed the maximum number of publication records (92.92 percent). India became the top most producers of research publications in terms of number (1502), whereas USA published 1075 records and received the highest citation score of 125 . The study also found out that first twenty authors contributed 2.6 percent of publications. In terms of authorship pattern, Sahebkar, A from Mashhad University of Medical Sciences published 73 records to his credit with 3212 citations, while Aggarwal BB from University of Texas received the huge number of 21325 citations from 67 publications. The first twenty institutions were found to have contributed 17.81 percent of the total publication records and 21.22 percent of the citations received. 583 authors published 107 records from the institution of Mashhad University of Medical Sciences, Iran.

The first twenty journals contributed 13.49 percent of publications and received 16.01 percent of citations. With an Impact Factor of 6.306, the Journal Food Chemistry stood at the first place, thereby contributing 70 publications with 3639 citations. The maximum publication of 6 records emerged from the conference of third World Congress on Medicinal and Aromatic Plants held at Thailand in 2003 and the maximum records of 318 was funded by the funding agency of National Natural Science Foundation of China. The highest citation score of 2687 was received for the article Bioavailability of curcumin: Problems and Promises by Preetha Anand, Ajaikumar B Kunnumakkara, Robert A Newman, etal. has published in the journal of Molecular Pharmaceutics 4 th volume, $6^{\text {th }}$ issue, November -December 2007.

\section{References}

1. Abrizah A, Kiran K, Erfanmanesh M, Zohoorian-Fooladi N \& Zainab A N, A bibliometric study on the worldwide research productivity of scientists in Elaeis guineensis Jacq. and Elaeis oleifera. Journal of Oil Palm Research, 2012. 24, 1459-1472.

2. Ahmed K M, Gupta B M and Gupta R, Curcuma longa (medicinal plant) research: A scientometric assessment of global publications output during 1997-2016. Pharmacognosy Journal, 2018, 10(5).

3. Alhaider I, Ahmed M K and Gupta B M, Global research output on date palm (Pheonix dactylifera): a 12 years scientometric perspective. Scientometrics, 2014, 98(1), 157-171.

4. Amalraj A, Pius A, Gopi S and Gopi S, Biological activities of curcuminoids, other biomolecules from turmeric and their derivatives-A review. Journal of traditional and complementary medicine, 2017, 7(2), 205-233.

5. Amsaveni N and Manikandan M, Management Information System Research output: A Scientometric Study. Journal of Current Trends in Library and Information Science: International Refereed Journal. 2014 (1), 51-55.

6. Amsaveni N and Vasanthi R, Mapping of Green Biotechnology Research a Scientometric Analysis. Journal of Advances in Library and Information Sciences, 2012, 1(4), 181-185.

7. Anwar M A, Phoenix dactylifera L: A bibliometric study of the literature on date palm. Malaysian Journal of Library \& Information Science, 2006, 11(2), 41-60.

8. Ashok Kumar P, Navalur S A and Sivasekaran K, A Scientometric Study of Biodiversity Research in India: A special review. International Journal of Scientific Research. 2013. 2(3).

9. Changtam C, de Koning H P, Ibrahim H, Sajid M S, Gould M K and Suksamrarn, A, Curcuminoid analogs with potent activity against Trypanosoma and Leishmania species. European journal of medicinal chemistry, 2010, 45(3), 941-956.

10. Chattopadhyay I, Biswas K, Bandyopadhyay U and Banerjee R K, Turmeric and curcumin: Biological actions and medicinal applications. Current Science-Bangalore, 2004, 87, 44-53.

11. Che D Y, Shien J H, Tiley L, Chiou S S, Wang S Y, Chang T J and Hsu W L, Curcumin inhibits influenza virus infection and haemagglutination activity. Food Chemistry, 2010, 119(4), 1346-1351.

12. Chithiraivel S, Sivasekaran K and Ramalinagam Jeyshankar, "Global Research output on Eosinophilia Literature: A Scientometric Analysis" Library Philosophy and Practice (e-journal). 2020, 4040.

13. Ciavarella C, Motta I, Valente S and Pasquinelli G, Pharmacological (or Synthetic) and Nutritional Agonists of PPAR- $\gamma$ as Candidates for Cytokine Storm Modulation in COVID-19 Disease. Molecules, 2020, 25(9), 2076.

14. Cooney J M, Barnett M P, Dommels Y E, Brewster D, Butts C A, McNabb W C and Roy N. C, A combined omics approach to evaluate the effects of dietary curcumin on colon inflammation in the 
Mdr1a-/- mouse model of inflammatory bowel disease. The Journal of Nutritional Biochemistry, 2016, 27, 181-192.

15. Gupta B M and Ahmed K M, Research on Azadirachta indica: A scientometric assessment of global publications output during 1997-2016. International Journal of Pharmaceutical Investigation, 2018, 8(4), 164-172.

16. Haghani M, Bliemer M C, Goerlandt F and Li J, The scientific literature on Coronaviruses, COVID-19 and its associated safety-related research dimensions: A scientometric analysis and scoping review. Safety Science, 2020, 104806.

17. Kamatchi Sivasekaran Dr., Stanleay Prabakar Dr., Subramanian Chithiraivel Dr., Ashok Kumar P Dr. and Arumugam Thirumagal Dr. "Electric Car: A Research Impact BY Means OF Scientometric Analysis", Library Philosophy and Practice (e-journal). 2019, 3660.

18. Kawasaki K, Okuda-Hanafusa C, Aoyagi M, Taoka K, Yamamoto N, Muroyama K and Yamamoto Y, Inhibitory effect of the compounds from the water extract of Curcuma longa on the production of PGE2 and NO in a macrophage cell line stimulated by LPS. Bioscience, Biotechnology, and Biochemistry, 2018, 82(12), 2109-2117.

19. Kim T, Davis J, Zhang A J, He X and Mathews S T, Curcumin activates AMPK and suppresses gluconeogenic gene expression in hepatoma cells. Biochemical and biophysical research communications, 2009, 388(2), 377-382.

20. Konur O, The scientometric evaluation of the research on the algae and bio-energy. Applied energy, 2011, 88(10), 3532-3540.

21. Laksham S, Surulinathi M, Balasubramani R and Srinivasaragavan S, Mapping the Research output on Coronavirus: A Scientometric Study. Gedrag \& Organisatie Review, 2020, 33(2), 163-185

22. Mahmood K, Zia K M, Zuber M, Salman M and Anjum M N, Recent developments in curcumin and curcumin based polymeric materials for biomedical applications: A review. International journal of biological macromolecules, 2015, 81, 877-890.

23. Mulik R S, Monkkonen J, Juvonen R O, Mahadik K R and Paradkar A R, Transferrin mediated solid lipid nanoparticles containing curcumin: enhanced in vitro anticancer activity by induction of apoptosis. International journal of pharmaceutics, 2010, 398(1-2), 190-203.

24. Muthuraj Surulinathi, Balasubramani R and Amsaveni N, "COVID-19 research output in 2020: The Global Perspective using Scientometric Study" (2020). Library Philosophy and Practice (e-journal). 4196.

25. Paramasivam M, Poi R, Banerjee H, and Bandyopadhyay A, High-performance thin layer chromatographic method for quantitative determination of curcuminoids in Curcuma longa germplasm. Food Chemistry, 2009, 113(2), 640-644.

26. Prasad S and Tyagi A K, Curcumin and its analogues: a potential natural compound against HIV infection and AIDS. Food \& function, 2015, 6(11), 3412-3419.

27. Ragavan S S, Surulinathi M and Neelakandan B, Indian perspective of medicinal plant research: A Scientometric study. International Journal of Plant, Animal and Environmental Sciences, 2012, 2(3), 195-203.

28. Ramasamy R U, Sivasekaran K and Navasakathi C, Scientometric Analysis of Thorium Research in India: A Case study. Global Research Analysis, 2013, 4, 80-82.

29. Ravindran P N, Babu K N and Sivaraman K (Eds.), Turmeric: the genus Curcuma. 2007, CRC press.

30. Reddy, P. S., Begum, N., Mutha, S., \& Bakshi, V. (2016). Beneficial effect of Curcumin in Letrozole induced polycystic ovary syndrome. Asian Pacific Journal of Reproduction, 5(2), 116-122.

31. Richart S M, Li Y L, Mizushina Y, Chang Y Y, Chung T Y, Chen G H and Hsu W L, Synergic effect of curcumin and its structural analogue (Monoacetylcurcumin) on anti-influenza virus infection. journal of food and drug analysis, 2018, 26(3), 1015-1023.

32. Singh N, Scientific output on Azadirachta Indica (Neem): A bibliometric study. SRELS Journal of Information Management, 2017, 53(6), 479-485.

33. Sivankalai S and Badhusha, K N, Bibliometric study on COVID 19 Outbreak. International Journal of Library and Information Studies, 2020, 10(2), 1-19.

34. Sivasekaran K Dr., Stanleay Prabakar Dr. and Ashok Kumar P Dr., "Mapping the Study and Awareness on Early Death Research: A scientometric Analysis" Library Philosophy and Practice (e-journal).2020, 4368 .

35. Sivasekaran K, Literature Output on Rice in India: A Scientometric Study. Journal of Advances in Library and Information Science, 2015, 4(1), 40-47.

36. Sivasekaran K and Srinivasa Ragavan S, Journal of astrophysics and astronomy: A bibliometric study. e-Library Science Research Journal, 2014, 2(6), 1-5.

37. Siviero A, Gallo E, Maggin, V, Gori L, Mugelli A, Firenzuoli F and Vannacc, A, Curcumin, a golden spice with a low bioavailability. Journal of Herbal Medicine, 2015, 5(2), 57-70. 
Curcuma Longa (Medicinal Plant) Research: A Scientometric Assessment of Global Publications

Output with Reference to Web of Science

38. Vivekanandhan S, Sivasamy K and Prabhakar S, Publications and Citations Analysis of Pollution Control Research Output from SCOPUS Database: A Scientometrics Analysis. International Journal of Next Generation Library and Technologies, 2016, 2(3), 1-13. 